https://doi.org/10.15407/ujpe65.11.973

P. PANPROM,${ }^{1}$ P. SRITONWONG,${ }^{1}$ S. LIMWICHIAN,${ }^{2}$ P. EIAMCHAI,${ }^{2}$ V. PATTHANASETTAKUL, ${ }^{2}$ N. NUNTAWONG ${ }^{2}$ M. HORPRATHUM, ${ }^{2}$ C. NAWANIL ${ }^{1,3}$

${ }^{1}$ Program of Physics, Faculty of Science, Udon Thani Rajabhat University (Udonthani 41000, Thailand; e-mail: ppanprom@gmail.com)

${ }^{2}$ National Electronics and Computer Technology Center (Pathum Thani 12120, Thailand)

${ }^{3}$ Aavanced Materials Research Unit, Faculty of Science, King Mongkut's Institute of Technology Ladkrabang (Bangkok 10520, Thailand)

\title{
EFFECT OF SPUTTERING POWER ON OPTICAL PROPERTIES OF NICKEL OXIDE ELECTROCHROMIC THIN FILMS
}

\begin{abstract}
The preparation and characterization of nickel oxide (NiO) thin film for electrochromic smart window applications are studied. The NiO thin film was prepared by the DC magnetron sputtering from a pure nickel target. The sputtering power was varies in the interval 50-200 W. The crystallinity and physical morphology of NiO films are characterized by X-ray diffraction (XRD) and field emission scanning electron microscopy (FE-SEM), respectively. The XRD result revealed that polycrystalline NiO thin films with preferred growth directions along (111) and (200) planes are obtained. Moreover, the electrochromic property of NiO thin films was investigated with a $U V$-Visible spectrophotometer. The colored state of the electrochromic cell was obtained by the ion insertion at the 1 - $V$ external applied bias in $0.1 \mathrm{M} \mathrm{KOH}$. The reversibility between the colored and bleached states is confirmed by the optical transmittance. The result shows the optical contrast as high as 28.68.
\end{abstract}

Ke ywords: electrochromic, nickel oxide, DC magnetron sputtering.

\section{Introduction}

Glass is one of the most popular building materials. The transparency of glass opens up the vision between the inside of a building and the outside world. This is aesthetically desirable, but not energetically favorable, as the solar heat directly passed through the buildings. The control over the transmittance of visible sunlight and solar heat into a building is of importance for the energy consumption. Electrochromic coatings (EC) are switchable thin-film coat-

(C) P. PANPROM, P. SRITONWONG, S. LIMWICHIAN,

P. EIAMCHAI, V. PATTHANASETTAKUL,

N. NUNTAWONG, M. HORPRATHUM,

C. NAWANIL, 2020

ISSN 2071-0194. Ukr. J. Phys. 2020. Vol. 65, No. 11 ings applied to glass or plastic that reversibly change the optical transmission with a small applied voltage [1]. It can control the daylight and solar heat passing through buildings. A conventional EC window consists of an EC layer, an electrolyte layer, and an ion storage counter electrode sandwiched between two transparent conducting layers $[2,3]$.

Nickel oxide shows a great promise as an active electrochromic material due to the high coloration efficiency $(\mathrm{CE})$, good cyclic reversibility, and low cost $[4,5]$. Thin film of $\mathrm{NiO}$ is widely used as the counter electrode layers in EC devices [4, 6, 7]. Various techniques have been used to deposit $\mathrm{NiO}$ thin films $[6$, $8,9]$, but the sputtering technique is the most widely investigated, because the large-scale deposition sets 

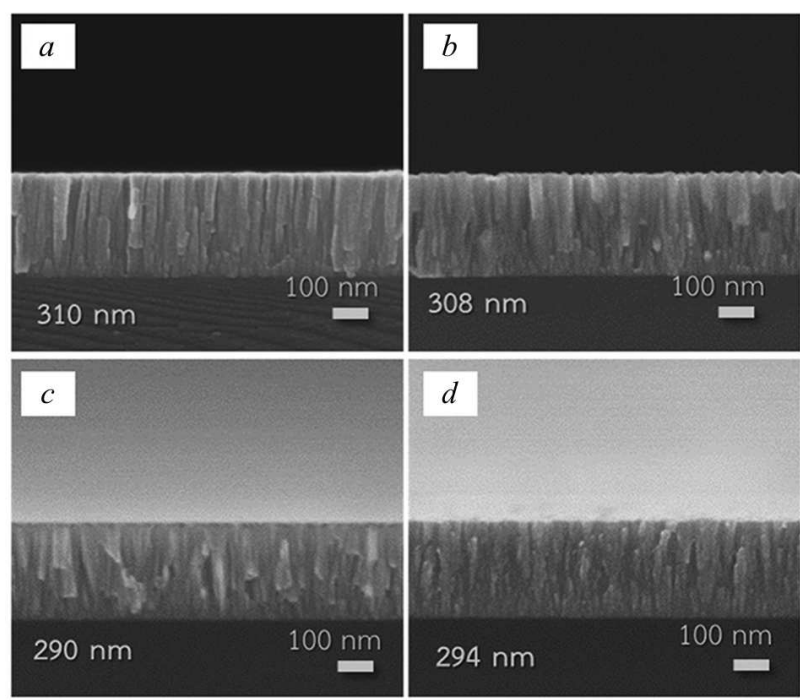

1. FE-SEM cross-section images of $\mathrm{NiO}$ thin films deposited on ITO glass at various DC power: $50 \mathrm{~W}(a), 100 \mathrm{~W}$ $(b), 150 \mathrm{~W}(c)$, and $200 \mathrm{~W}(d)$ with roughly $300 \mathrm{~nm}$ thickness

are available, and high-quality films are obtained $[4,7,10]$.

In this research, $\mathrm{NiO}$ thin films were deposited by the DC magnetron sputtering technique. The influence of the sputtering power on optical properties is investigated. The reversibility between colored and bleached state was confirmed by the optical transmittance. Moreover, the crystallinity and physical morphology of the $\mathrm{NiO}$ films were characterized by X-ray diffraction (XRD) and field emission scanning electron microscopy (FE-SEM), respectively.

\section{Experimental Details}

In this research, $\mathrm{NiO}$ films were formed using the reactive direct-current magnetron sputtering on glass substrates coated with an indium tin oxide (ITO) commercial sheet resistance of $11.5 \Omega / \square$. First, the ITO glasses were ultrasonically cleaned in ethanol

Deposition rate of $\mathrm{NiO}$ films

deposited at different $\mathrm{DC}$ powers for $30 \mathrm{~min}$

\begin{tabular}{|c|c|}
\hline DC power $(\mathrm{W})$ & Deposition rate $(\mathrm{nm} / \mathrm{min})$ \\
\hline 50 & 2.78 \\
100 & 19.85 \\
150 & 33.40 \\
200 & 52.66 \\
\hline
\end{tabular}

and deionized water for $20 \mathrm{~min}$ in sequence. The pure $\mathrm{Ni}(99.99 \%)$ was used as a sputtered target. The base pressure of a sputtering chamber was $5 \times 10^{-6}$ mbar. Ar and $\mathrm{O}_{2}$ gases were introduced into the sputtering chamber through two mass flow controllers. The flow rates of $\mathrm{Ar}$ and $\mathrm{O}_{2}$ gases were fixed at 30 and $10 \mathrm{sccm}$, respectively. Then the effect of the sputtering power was studied. The power of a DC source was varied in the interval $50-200 \mathrm{~W}$.

The morphology and crystal structure of thin films were investigated by a field emission scanning electron microscope (FE-SEM, HITASHI/SU8030) and the grazing-incidence X-ray diffraction (GIXRD, Rigaku TTRAX III), respectively. The optical characteristics of thin films were investigated using a UV-Visible spectrophotometer (Agilent Technologies, Agilent Cary 7000) in the wavelength range 300$2000 \mathrm{~nm}$. The colored and bleached states of the electrochromic cell were investigated by the ion insertion at the $1-\mathrm{V}$ external applied bias in $0.1 \mathrm{M} \mathrm{KOH}$.

\section{Results and Discussion}

First, the thin films were deposited at different DC powers in the interval $50-200 \mathrm{~W}$ for $30 \mathrm{~min}$. The calculated deposition rate of $\mathrm{NiO}$ films are shown in Table. The deposition rates were $2.78,19.85,33.40$, and $52.66 \mathrm{~nm} / \mathrm{min}$ for powers of $50,100,150$, and $200 \mathrm{~W}$, respectively. The result shows that the deposition rate of thin films increases with the DC power due to the higher kinetic energy of generated sputtered particles as the DC power is increased [11].

The influence of the DC power on the morphology of the structure of $\mathrm{NiO}$ films was revealed by field emission scanning electron microscopy (FESEM). Figure 1 shows the morphological feature of as-deposited $\mathrm{NiO}$ thin films with roughly $300 \mathrm{~nm}$ thickness deposited at different DC powers in the interval 50-200 W. The cross-section SEM images of all $\mathrm{NiO}$ thin films show a homogeneously columnlike film. The column orientation was perpendicular to the surface of the substrate. The cross-sectional image shows that the thin films presented a compact columnar structure as showed in Fig., $1, a-d$.

Figure 2 shows top-view FE-SEM images for $\mathrm{NiO}$ thin films deposited on Si glass at different DC powers. The average grain sizes of $\mathrm{NiO}$ were $21.2 \pm 2.5$, $27.3 \pm 4.2,30.1 \pm 3.8$, and $25.2 \pm 6.5 \mathrm{~nm}$ for the $\mathrm{DC}$ power of $50,100,150$, and $200 \mathrm{~W}$, respectively. It is

ISSN 2071-0194. Ukr. J. Phys. 2020. Vol. 65, No. 11 


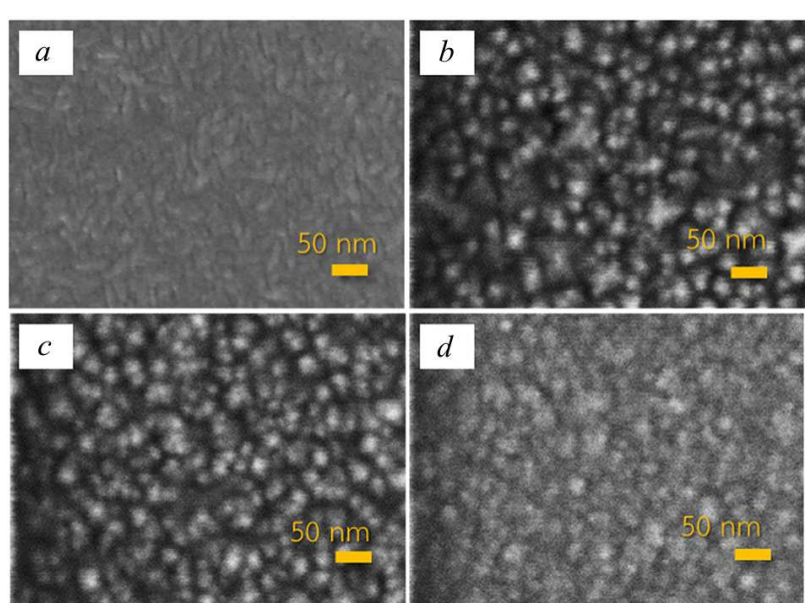

Fig. 2. Top-view FE-SEM images of NiO thin films deposited on ITO glass at different DC powers: $50 \mathrm{~W}(a), 100 \mathrm{~W}(b)$, $150 \mathrm{~W}(c)$, and $200 \mathrm{~W}(d)$, with roughly $300 \mathrm{~nm}$ thickness

notable that the grain size of $\mathrm{NiO}$ tends to increase, as the sputtering power increases to $150 \mathrm{~W}$, and the grain size of $\mathrm{NiO}$ decreases for higher sputtering powers. The excessive supply of the sputtering power at $200 \mathrm{~W}$ limits the growth of crystalline grains due to the very high deposition rate [12], as shown in Table.

The XRD patterns of as-deposited $\mathrm{NiO}$ thin films as a function of the DC power are shown in Fig. 3. The result indicates that the film deposited at a $\mathrm{DC}$ power of $50 \mathrm{~W}$ shows a suboxide of $\mathrm{Ni}$. The well-defined polycrystalline structure of $\mathrm{NiO}$ was not obtained. According to the XRD results, it was found that the XRD peaks become gradually sharper, as the DC power increases from 50 to $150 \mathrm{~W}$, indicating a larger particle size and the better crystallinity of the deposited films. The energy of the sputtered atom arriving at the substrate increases with the sputtering power to $150 \mathrm{~W}$ and facilitates a further crystallization [13]. The XRD pattern revealed that NiO films deposited at DC powers of 100 and $150 \mathrm{~W}$ exhibit the polycrystallinity with a standard face-centered cubic structure which matching well with the JCPDS card No. 47-1049 of NiO [7]. The polycrystalline films show a well-defined peaks at $2 \theta=37.04^{\circ}, 43.28^{\circ}$, $62.81^{\circ}$, and $75.47^{\circ}$ which corresponded to the reflection of (111), (200), (220), and (311) planes, respectively. The thin films deposited at DC powers of 100 and $150 \mathrm{~W}$ show a preferred (200) and (111) orientations, respectively. Any reflection peaks from the impurities in XRD spectra could not be observed. Ho-

ISSN 2071-0194. Ukr. J. Phys. 2020. Vol. 65, No. 11

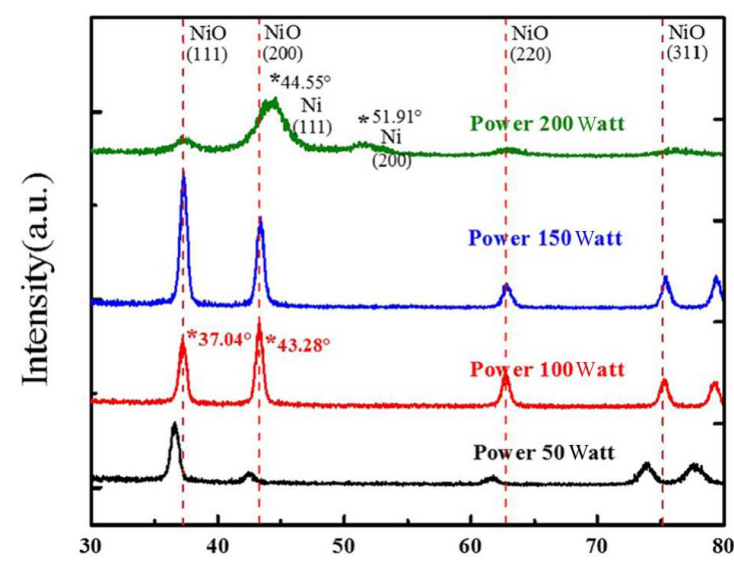

Fig. 3. XRD patterns of as-deposited $\mathrm{NiO}$ thin films as a function of the DC power

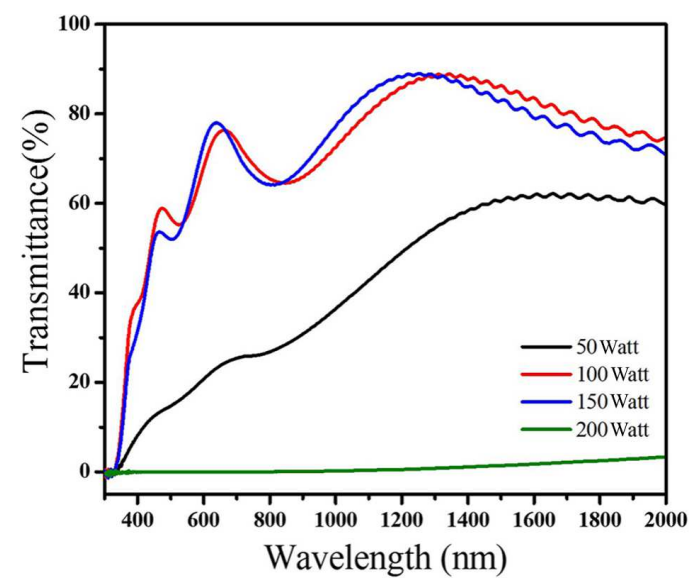

Fig. 4. Transmittance spectra of the $\mathrm{NiO}$ thin films deposited at different DC powers

wever, the peak intensity extremely decreases with increasing the DC power to $200 \mathrm{~W}$. The structures gradually transfer from metal oxide to metallic mode. The XRD pattern show the peaks at $2 \theta=$ $44.55^{\circ}$ and $51.91^{\circ}$ which correspond to the reflection of (111) and (200) planes of $\mathrm{Ni}$ [14]. This result may be due to the excessive amount of $\mathrm{Ni}$ atoms ejected from the target at a high DC power. There is no sufficient amount of oxygen to react with the flux of sputtered metal species to form stoichiometric oxides.

Figure 4 shows the transmittance spectra of the $\mathrm{NiO}$ films. The result indicates that the transmittance tends to increase with the DC power in the range of 50-150 $\mathrm{W}$. The transmittances at the wavelength of $550 \mathrm{~nm}$ (which is most sensitive to the eye) are approximately 25,76 , and $78 \%$ for DC powers of 

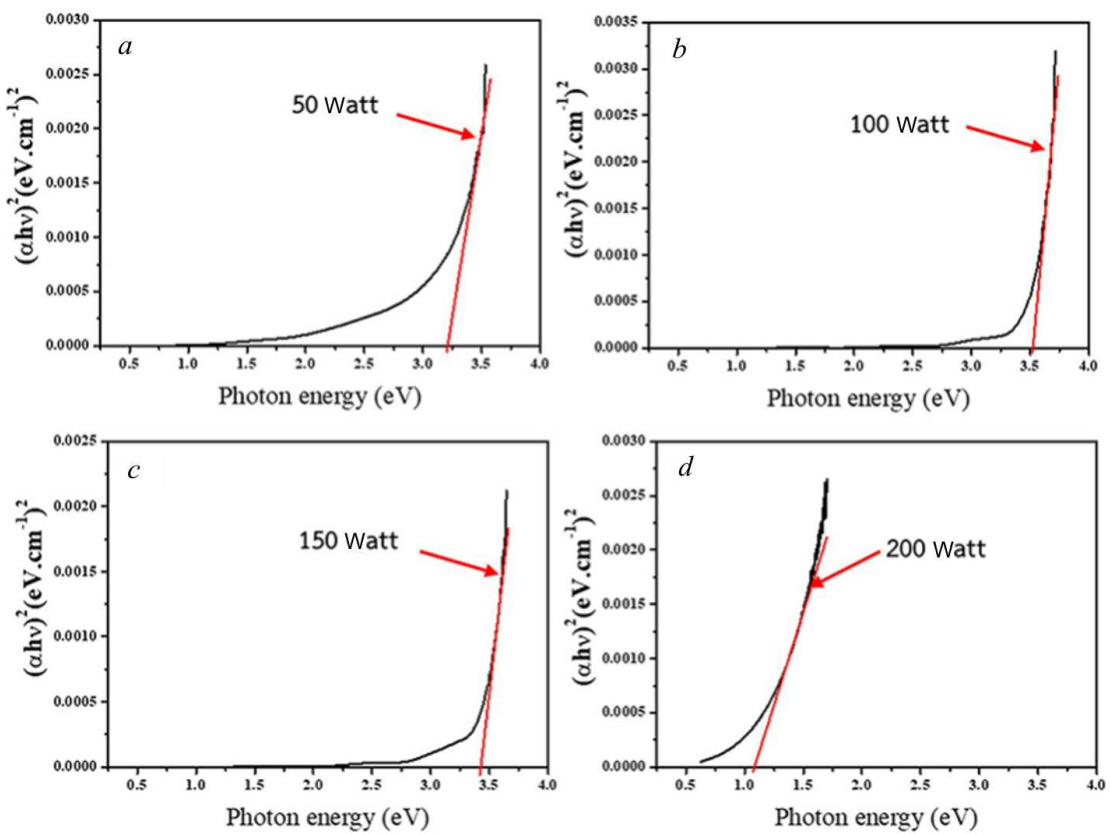

Fig. 5. $(\alpha h \nu)^{2}$ vs the photon energy for NiO films deposited at different DC powers: $50 \mathrm{~W}(a), 100 \mathrm{~W}(b), 150 \mathrm{~W}$, and $200 \mathrm{~W}(c)$
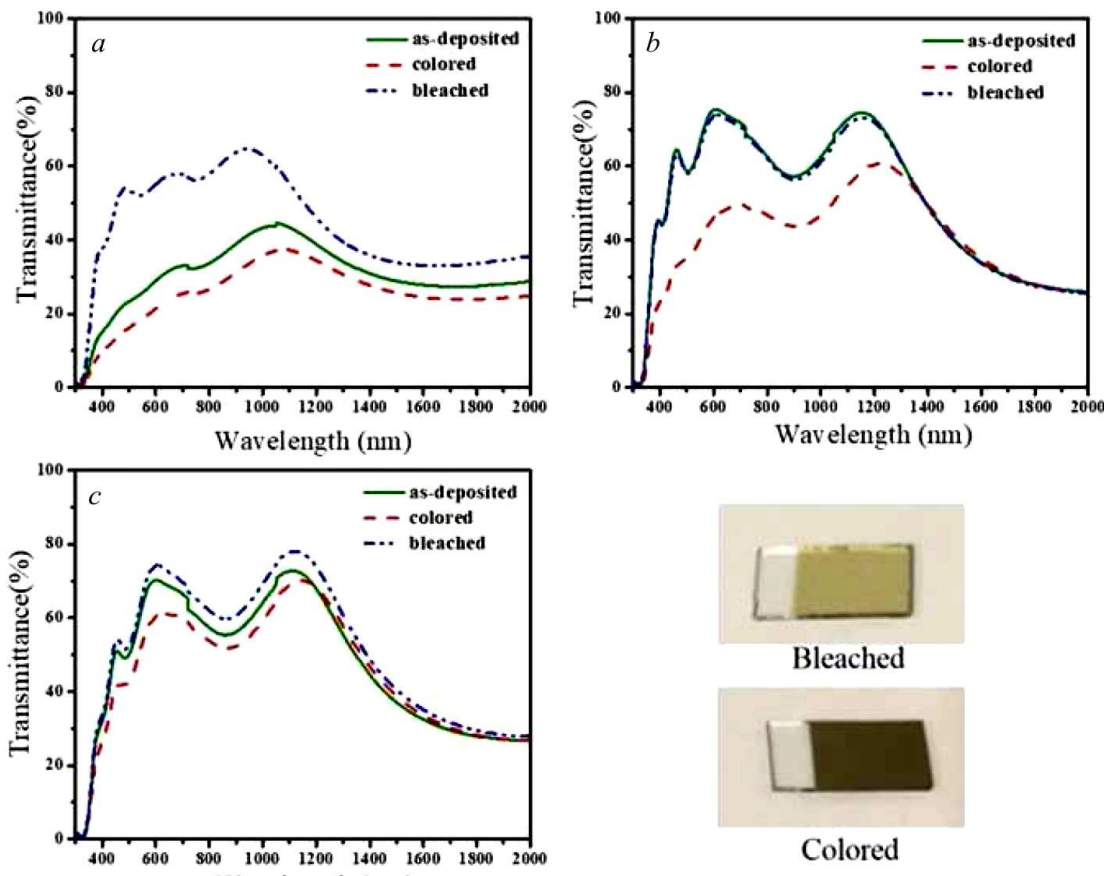

Fig. 6. Optical transmittance spectra of $\mathrm{NiO}$ films deposited at different $\mathrm{DC}$ powers: $50 \mathrm{~W}(a), 100 \mathrm{~W}(b)$, and $150 \mathrm{~W}(c)$, in the as-deposited, bleached, and colored states. The inset shows photographs of the materials in the bleached and colored states 
50,100 , and $150 \mathrm{~W}$, respectively. The $\mathrm{NiO}$ film deposited with the 200-W DC power was found to be opaque in the UV to NIR region. This result is caused by the presence of $\mathrm{Ni}$ metal, which corresponds to the XRD results. From the transmittance spectra, it is found that the electrochromic films with good visible transparency were obtained using DC powers of 100 and $150 \mathrm{~W}$.

Figure 5 shows the plot of $(\alpha h \nu)^{2}$ with the photon energy in the wavelength range $300-2000 \mathrm{~nm}$ at room temperature. The extrapolation of the straight line into the higher energy region gives the value of the direct band gap of the $p$-type Ni. We have assumed that the $\mathrm{NiO}$ films are characterized by a direct band gap, as stated for the bulk $\mathrm{NiO}$ material. If the $\mathrm{DC}$ power is increased from 50 to $100 \mathrm{~W}$, then the band gap width $\left(E_{g}\right)$ increases from $3.2 \mathrm{eV}$ to $3.5 \mathrm{eV}$. For the film deposited at a DC power of $150 \mathrm{~W}$, the band gap width slightly decreased to $3.4 \mathrm{eV}$. When the DC power increases to $200 \mathrm{~W}$, the band gap width extremely decreases to $1.1 \mathrm{eV}$. This result is caused by the presence of $\mathrm{Ni}$ metal, which corresponds to the XRD results. The highest band gap width equal to $3.5 \mathrm{eV}$ is obtained for the film deposited at the 100W DC power.

In-situ spectroelectrochemical experiments were used to evaluate the electrochromic properties of electrodeposited nickel oxide on the ITO substrate. In Fig. 6, the measured transmittance in the UV-VISNIR (300-2000 nm) range of a nickel oxide film in $\mathrm{KOH}$ electrolytes is presented. The measurements have been done both in the bleached and colored states after the application of $-1.0 \mathrm{~V}$ for $30 \mathrm{~s}$ and $+1.0 \mathrm{~V}$ for $30 \mathrm{~s}$, respectively. The inset in this figure shows representative photographs of the materials in the bleached and colored states. The color of nickel oxide switches from light brown (bleached) to dark brown (colored) at potentials which are governed by the $\mathrm{Ni}(\mathrm{II})$ to $\mathrm{Ni}(\mathrm{III})$ redox process [5, 7]. From Fig. 6 , it os seen that the change in the transmittance $(\Delta T)$ between the colored (red line) and bleached states (blue lines) are $31.01,28.68,15.89$, and $0 \%$ at the wavelength of $550 \mathrm{~nm}$ (which is most sensitive to the eye) for the films deposited at DC powers of 50 , 100,150 , and $200 \mathrm{~W}$, respectively. The nickel oxide film deposited at a DC power of $50 \mathrm{~W}$ has a highest optical contrast between the bleached and colored state. However, the optical transmittance in the bleached state could not returned to that of the as- deposited state. The nickel oxide film deposited at a DC power of $100 \mathrm{~W}$ has a relatively high optical contrast between the bleached and colored state. Moreover, it is seen that the optical transmittance in the bleached state is very close to the as-deposited state. As the DC power increases from $100 \mathrm{~W}$ to $150 \mathrm{~W}$, the sample tends to have lower optical transmittance. Therefore, the electrochromic films with good electrochromic properties were obtained by using a DC power of $100 \mathrm{~W}$. The cause is that the $100-W$ DC power sample has smaller microcrystallite sizes as indicated by the XRD results. The boundary and surface of $\mathrm{NiO}$ microcrystallites are key factors in determining the electrochromism. In the research of Yoshimura et al. [15], they reported that the boundary acts as an active site in the electrochromic reaction. As microcrystallite sizes are small, many active sites which are related to the coloration are formed. For the sample deposited at a DC power of $200 \mathrm{~W}$, the optical transmittance is absent due to the $\mathrm{NiO}$ films were transform to metal nickel, as is shown by the XRD results.

\section{Conclusions}

In this work, $\mathrm{NiO}$ thin films were deposited on glass by using the DC magnetron sputtering technique. The optical properties of $\mathrm{NiO}$ films at different DC powers are analyzed. The results reveal that the deposition rate of $\mathrm{NiO}$ films increases with the DC power. According to the XRD and SEM results, the high-purity polycrystalline $\mathrm{NiO}$ is obtained under the deposition with DC powers in the range of 50$150 \mathrm{~W}$. The films deposited with DC powers of 100 and $150 \mathrm{~W}$ exhibit more than $75 \%$ of transmittance in the visible light region. The highest band gap width $E_{g}=3.5 \mathrm{eV}$ is obtained for the film deposited at the $100-W$ DC power. The nickel oxide film deposited at a DC power of $100 \mathrm{~W}$ has a relatively high optical contrast between the bleached and colored states with a $\Delta T$ of $28.68 \%$. Moreover, the optical transmittance in the bleached state was very close to the as-deposited state. These results all supported the use of $\mathrm{NiO}$ as electrochromic coatings applied in glazing units for buildings and automobiles.

This research was supported by Opto-Electrochemical Sensing Research Team (OEC), National Electronics and Computer Technology Center (NECTEC), Pathumthani, Thailand. 
1. H.N. Cui, M.F. Costa, V. Teixeira, I. Porqueras, E. Bertran. Electrochromic coatings for smart windows. Surf. Sci. 532-535, 1127 (2003).

2. E.L. Runnerstrom, A. Llorde, S.D. Lounisac, D.J. Milliron. Nanostructured electrochromic smart windows: Traditional materials and NIR-selective plasmonic nanocrystals. Chem. Commun. 50, 10555 (2014).

3. W. Cheng, M. Moreno-Gonzalez, K. Hu, C. Krzyszkowski, D.J. Dvorak, D.M. Weekes, B. Tam, C.P. Berlinguette. Solution-deposited solid-state electrochromic windows. Science 10, 80 (2018).

4. M. Da Rocha, A. Rougier. Electrochromism of non-stoichiometric $\mathrm{NiO}$ thin film: as single layer and in full device. Appl. Phys. A 122, 1 (2016).

5. M.P. Browne, H. Nolan, N.C. Berner, G.S. Duesberg, P.E. Colavita, M.E.G. Lyons. Electrochromic nickel oxide films for smart window applications. Int. J. Electrochem. Sci. 11, 6636 (2016).

6. H. Huang, J. Tian, W.K. Zhang, Y.P. Gan, X.Y. Tao, X.H. Xia, J.P. Tu. Electrochromic properties of porous $\mathrm{NiO}$ thin film as a counter electrode for $\mathrm{NiO} / \mathrm{WO}_{3}$ complementary electrochromic window. Electrochim. Acta. 56, 4281 (2011).

7. Q. Liu, Q. Chen, Q. Zhang, Y. Xiao, X. Zhong, G. Dong, M.P. Delplancke-Ogletre, H. Terryn, K. Baert, F. Reniers, X. Diao. In-situ electrochromic efficiency of nickel oxide thin film: Origin of electrochemical process and electrochromic degradation. J. Mater. Chem. C 6, 646 (2017).

8. D. R. Sahu, T.J. Wu, S.C. Wang, J.L. Huang. Electrochromic behavior of $\mathrm{NiO}$ film prepared by e-beam evaporation. J. Sci.: Advanced Materials and Devices 2, 225 (2017).

9. F. Ozutok, S. Demiri, E. Ozbek. Electrochromic NiO thin films prepared by spin coating. AIP Conf. Proc. 1815, 050011 (2017).

10. M. Guziewicz, J. Grochowski, M. Borysiewicz, E. Kaminska, J.Z. Domagala, W. Rzodkiewicz, B.S. Witkowski, K. Golaszewska, R. Kruszka, M. Ekielski, A. Piotrowska. Electrical and optical properties of $\mathrm{NiO}$ films deposited by magnetron sputtering. Opt. Appl. 41, 431 (2011).

11. K.M. Nair, S. Priya. Advances and Applications in Electroceramics II: Ceramic Transactions (Wiley, 2012), Vol. 235 [ISBN: 9781118273357].
12. D.J. Kwak, M.W. Park, Y.M. Sung. Discharge power dependence of structural and electrical properties of Al-doped $\mathrm{ZnO}$ conducting film by magnetron sputtering (for PDP). Vacuum 83, 113 (2009).

13. A. Chaoumead, Y. Sung, D.J. Kwak. The effects of RF sputtering power and gas pressure on structural and electrical properties of ITO thin film. Adv. Cond. Matter Phys. 2012, 1 (2012).

14. K.S. Dijith, R. Aiswarya, M. Praveen, S. Pillai, K.P. Surendran. Polyol derived $\mathrm{Ni}$ and NiFe alloys for effective shielding of electromagnetic interference. Mater. Chem. Front. 2, 1829 (2018).

15. K. Yoshimura, T. Miki, S. Tanemura. Nickel oxide electrochromic thin films prepared by reactive DC magnetron sputtering. Jpn. J. Appl. Phys. 34, 2440 (1995).

Received 09.09.19

П. Панпром, П. Срітонвонг,

С. Лімвічан, П. Еямчай, В. Патханасетакул,

Н. Нунтавонг, М. Хорпратхум, Ч. Наваніл

ЗАЛЕЖНІСТЬ ОПТИЧНИХ ВЛАСТИВОСТЕЙ ТОНКИХ ЕЛЕКТРОХРОМНИХ ПЛІВОК ОКСИДУ НІКЕЛЮ ВІД ПОТУЖНОСТІ НАПИЛЕННЯ

$\mathrm{P}$ е з ю м е

Досліджено процес виготовлення і параметри тонких плівок $\mathrm{NiO}$ для застосування в електрохромних смарт-вікнах. Плівки зроблені методом магнетронного напилення з постійним струмом із використанням мішені з чистого нікелю. Потужність напилення змінювалась у межах 50-200 Вт. Кристалічна структура та морфологія плівок $\mathrm{NiO}$ визначені методами дифракції рентгенівських променів (ДРП) і сканувальної електронної мікроскопії (CEM), відповідно. Результати ДРП показують кращий ріст полікристалічних плівок в площинах (111) і (200). Крім того, електрохромні властивості тонких плівок $\mathrm{NiO}$ вивчались за допомогою спектрофотометра ультрафіолетового та видимого діапазону. Забарвлений стан електрохромної комірки отримано введенням іонів з концентрацією $0,1 \mathrm{M} \mathrm{KOH} \mathrm{при} \mathrm{зміщен-}$ ні 1 В. Оборотність переходів між забарвленим і безбарвним станами підтверджено за допомогою коефіцієнта пропускання. Знайдено, що величина оптичного контрасту досягає 28,68 . 